\title{
Chinese public investment in Ecuador- an analysis of the motivational framework for Chinese state financing in the Latin American context
}

\author{
Antonia Ramm ${ }^{1}$
}

\begin{abstract}
The paper examines the underlying determinants of Chinese foreign finance allocation in Latin America and outlines the implications of these dynamics for receiver countries in the region. A case study on Ecuador is used in order to enrich the analysis with detail on country-level. Underlying drivers for aid allocation cannot be identified from the statistical analysis. However, the results do not lend support to the popular hypotheses of resource-driven or power-driven Chinese aid allocation either. In terms of less concessional financing, natural resource endowment results as the driving factor for Chinese fund allocation while the findings suggest that the country's risk profile and investment environment play a minor role in Chinese public financing.
\end{abstract}

\section{Introduction}

The last two decades will go down in history as the years of transformation of the traditional world order. While the United States (US) are still shaken by their recent election results, China has already begun to fill the vacuum, the once most powerful country has left behind. Latin America, which has traditionally been within the influence sphere of the US, serves as a prime example of these dynamics. In recent years, the region has received increasing political and economic attention in the form of Chinese investments and strengthened bilateral ties with China that are likely to be complemented by collaboration in strategic dimensions. In the meantime, the US has found itself tied up in domestic affairs and strong presence in the Middle East (Diaz, Jr. \& Lee, 2009). With growing Chinese public investment all over the world, the allocation method of China's funding and its underlying determinants has become a widely debated topic. Particularly Western dominated media and public figures have accused China of supporting undemocratic and authoritarian leaders in resource-rich countries, tying donation and investments to political favors or using receiver countries' difficult situations to their advantage in order to negotiate exploitative deals (Tseng \& Krog, 2017; Lengauer, 2011; Alesina and Dollar, 2000). Counter to these arguments, Chinese officials explain the investments in countries outside the Western "mainstream portfolio" with a noninterventionist agenda, which emphasizes the importance of the recipient country's independence in choosing its own development path without external influence on development models or internal political affairs (Information Office of the State Council, People's Republic of China, 2011). In Latin America, this political stance has been welcomed particularly under the Pink Tide, a wave of left-leaning governments, which significantly reduced the cooperation with traditional financiers in order to increase their country's political independence (Azpuru, 2016).

\footnotetext{
1 Antonia Ramm graduated with a bachelor degree in Economics and Business Economics from Maastricht University in 2017. Currently, she works as a financial analyst at Telefonica Ecuador in Quito, Ecuador. Contact: a.ramm@alumni.maastrichtuniversity.nl
} 
However, sluggish economic growth in recent years has left the region in the need for liquidity injection from outside, which stresses China's importance as a donor country.

Ecuador poses an interesting example to investigate these developments as it is not only exemplifying the aforementioned characteristics, but also represents the third largest receiver of Chinese financing in Latin America (nominally), only to be topped by Brazil and Venezuela, countries with GDPs twenty-five times and three times the size of Ecuador's respectively (De la Torre \& Pallares, 2017). Hence, a case study on the country's development during the research period complements the empirical analysis on Chinese public financing within the larger Latin American country sample. The case study provides a context for Chinese state financing on the continent and adds detail and insight into underlying political and economic dynamics. Thus, the paper investigates the following research question.

How is the investment behaviour of public Chinese investors characterised in Latin America and Ecuador in particular? Specifically, which core variables drive the allocation of Chinese investment flows in Latin America and what are the implications for the receiver countries?

The paper aims to fill research gaps in at least two relevant aspects of Chinese state financing and its deeper determinants. Firstly, it investigates the motivational framework in the Latin American context, a region that has so far been neglected in academic research relative to the strength of the growing economic ties. Secondly, the qualitative analysis focuses on the Ecuadorian case, which highlights the importance of particular developments in the receiver country and the implications of Chinese state financing.

To analyse the allocation model of Chinese foreign finance, the paper sets out by evaluating existing literature on this and similar topics. Following the literature review, the Ecuadorian case study is outlined in order to analyse the influences on and conditions of Chinese public investments in the Latin American context. Next, perspectives are changed looking at China's underlying motivation for foreign finance allocation, particularly compared to traditional donors. The quantitative study is introduced by analysing deeper determinants of financial allocation with the help of a motivational model. It follows a statistical analysis of the data, the results and interpretations. Lastly, the author outlines implications and concludes.

\section{Literature review}

In the academic field, research on Chinese official financing is strongly concentrated, both in terms of investigative topics as well as geographic regions of interest. Nearly half of Chinese foreign aid funds (45.7\% in 2009) flow to the African continent while Latin America accounts for a meagre share of less than 15\% in 2009 (Information Office of the State Council, People's Republic of China, 2011). This, in parts, explains why most research on Chinese aid and state financing focuses on African countries. In terms of research agendas, many papers investigate the validity of the commonly held perception on Chinese "rogue aid", which puts Chinese national interest before receiver countries' needs in its aid allocation (Broich, 2017; Broich \& Szirmai, 2014; Dreher \& Fuchs, 2015; Dreher, Fuchs, Parks, Strange \& Tierney, 2015; Tseng \& Krog, 2017).

Dreher and Fuchs (2015) evaluate the determinants of China's aid allocation based on an econometric study for a set of 132 countries over a period of 50 years (1956-2006). They find significant support for the claim that political considerations play an important role in Chinese aid allocation, even though these tendencies are similar across all donors. The authors also note that natural resource

\section{Research \\ Papers}


endowment as well as the level of democracy and governance do not significantly influence the allocation of aid flows.

Dreher et al. (2015) follow a similar research agenda by investigating deeper determinants of Chinese official investments for a sample of 50 African recipient countries in the period between 2000 and 2012. The authors argue that the negative perception of non-Western donors stems from a lack of information, transparency and accurate measurement. By differentiating project flow classes within the data set into Official Development Assistance (ODA) and Other Official Flows (OOF), Dreher et al. (2015) are able to paint a more nuanced picture of the underlying determinants of Chinese official finance allocation. The terms ODA and OOF are commonly used by the Organisation for Economic Co-operation and Development (OECD) - Development Assistance Committee (DAC) in order to develop a common set of definitions and reporting standards on international financial flows. The DAC presents a forum within the OECD coordinating aid provision and development assistance (Zhang, 2016). The committee consists of 30, mainly Western countries that agree on certain reporting standards in the provision of foreign assistance in order to increase efficiency, effectiveness and transparency in the common effort of poverty reduction and development support (Dreher et al., 2015).

ODA flows are financial sources that are provided through official agencies to developing countries and multilateral institutions. Their mandate is to promote economic and social development, which is why these flow classes are concessional by nature (25\% grant element). In contrast, OOF flows do not primarily aim at assistance in economic development or do not comply with the characteristics of a $25 \%$ grant element. In terms of ODA flows, it is found that political interests play a significant role in the allocation while natural resource endowment, institutional quality and recipient government's regime type seem unrelated. Furthermore, poorer countries receive significantly more aid following humanitarian needs. On the contrary, OOF allocation is found to be associated with commercially driven objectives, in particular natural resource endowment. Thus, the authors conclude that determinants of Chinese public investments resemble traditional Western donors/ financiers. Confusion and resulting negative perception of Chinese aid is largely due to an incorrect measurement and aggregation of Chinese foreign aid projects (Dreher et al., 2015).

To my best knowledge, there are no studies conducting similar research on determinants of Chinese state financing in the Latin American context. However, several papers investigate the fastgrowing economic relationship between China and the Latin American continent, evaluating case studies in the natural resource industry (González-Vincente, 2013), trade relationships and bilateral ties (Domínguez et al., 2006) and policy challenges arising from increased Chinese presence (Wise an Quiliconi, 2007). Furthermore, public perception of Latin American citizens on rising Chinese involvement and resulting societal, ecological and cultural challenges attracted growing research attention (Azpuru, 2016; Armony \& Velásquez, 2015).

\section{The role of Chinese public financing in Ecuador}

The following section analyses the development of the bilateral relationship of China and Ecuador in order to highlight the specific factors which contributed to the role of China as a major donor country in Latin America. Even though some characteristics within the analysis are country-specific (e.g. dollarization), broader economic cycles, inherent political and institutional instability and the important role of natural resource endowments are comparable across the Latin American continent, which is why this study enriches the empirical analysis with detailed considerations. 
Stronger economic integration between China and Ecuador (and Latin America in general) only started with the turn of the century and progressively evolved from trade to other dimensions (Armony \& Velásquez, 2015). Since the discovery of oil reserves in the 1970s, Ecuador's dependence on petroleum increased progressively (González-Vincente, 2013). This development coincided with China's gradual opening of the economy, an active promotion of outward orientation and strong economic growth putting oil imports on top of China's economic agenda (Krauss \& Bradsher, 2015). Ecuador's volatile political and economic circumstances during this time laid the ground for the relationship between the countries. Within the last 20 years, four periods stand out, each of which features distinctive economic and political circumstances influencing the development of the Chinese-Ecuadorian cooperation.

\subsection{The financial crisis (1995-2000)}

The financial crisis and its build up in the late 1990s matter for various reasons. It represents not only the worst economic recession Ecuador had witnessed since the Great Depression, but also caused fundamental changes in the economic and political systems of the country due to the adoption of the dollar as official currency (Jácaume, 2004). Furthermore, dynamics in the 1990s bear considerable similarities with the current economic crisis, which emphasises the importance of an in-depth analysis. Lastly, the crisis is a prime example of Ecuador's high economic and political volatility, which has been a pronounced feature of the country's history. Jacome (2004) identifies three principal and reinforcing drivers underlying the financial crisis in the late 1990s, namely (a) institutional weaknesses, (b) rigidities in the fiscal management and (c) dollarization of the financial system.

Ecuador's economic and political path is marked by high instability and incoherence. Particularly in the build-up of the financial crisis, volatility played an important role hindering the development of strong and effective institutions, as the political landscape found no ground to establish clear rules. In the mid-1990s, several external shocks like the Tequila crisis ${ }^{2}$ and tensions on the Peruvian border caused a deterioration in macroeconomic performance and the external accounts, reinforced by unstable domestic politics. At this time, the underdeveloped institutional framework and the inability to obtain enough financing from external sources was not able to prevent external shocks and internal turmoil from developing into a systematic crisis, mainly because policy adoption was lacking credibility, speed and accuracy (Jácaume, 2004).

Next to institutional weaknesses, Ecuador also saw itself confronted with years of unsustainable fiscal management which further deteriorated market sentiment. By the late 1990s, Ecuador's lack of credibility, inappropriate regulation of the financial system and external shocks caused a run on several banks. The increased risk premium raised pressure on Ecuadorian banks' balance sheets already in a weak position due to years of sluggish economic performance, weak regulation and corrupt bank practices. The combination of weak institutions and rigidities in public finance left monetary policy as the only instrument to respond to liquidity shortfalls, depositor panic and social unrest. Even though an increase in money supply alleviated crisis symptoms in the short-run, prolonged quantitative easing lost its effectiveness and even deteriorated macroeconomic conditions through large hikes in interest rates. Eventually, the Central Bank's activities were bound to cause a currency crisis as desperate money printing only promoted inflation and weakened the already low depositor's credibility. Additionally, economic turmoil caused a "flight to safety" putting strong pressure on the Ecuadorian exchange rate. The gradual dollarization of the financial

2 Mexican currency and banking crisis caused by strong devaluation of the peso against the dollar in 1994 (Van der Moolen, 2013)

30 Research

Papers 
system initiated a downwards spiral of currency depreciation and dwindling foreign reserves. Finally, the default of external debts combined with the pre-mature unlocking of deposits escalated into further bank insolvencies and skyrocketing inflation. At this point, the official dollarization of the economy presented itself as the only means to restore stability (Jácaume, 2004).

\subsection{Ecuador's Golden Years (2000-2013)}

The dollarization of Ecuador's economy proved to be a success when the financial and economic system recovered gradually in 2000 (Jácaume, 2004). This rebound can in large parts be attributed to a thorough political re-organisation, rising oil prices and strong support by multilateral institutions (Jácaume, 2004). During the following decade, all Latin American countries benefited from favourable developments in terms of trade, rising demand from other emerging markets and great expansions of internal demand with growth rates peaking in 2011 (De la Torre \& Pallares, 2017). This decade represents one of Ecuador's most stable periods, both in economic and political terms (Skidmore, Smith \& Green, 2013). Even though it is often referred to as "Ecuador's Golden Years" implying a coherent economic development, it is divided into two sub-periods featuring different economic models and underlying factors of growth (De la Torre \& Pallares, 2017). This sub-division is crucial for the analysis of the influence of China within the distinctive periods.

\subsubsection{Economic recovery and growth (2000-2006)}

Increased demand for input factors and growing spending power due to strong economic growth in emerging markets (particularly China) boosted commodity prices in the early 2000 (Skidmore, Smith \& Green, 2013). Additionally, Ecuador found itself in a particularly favourable situation as the dollar depreciated against many currencies which made Ecuadorian export products more competitive, especially against neighbouring countries like Colombia and Peru (De la Torre \& Pallares, 2017). Despite favourable external conditions, the primary driver of growth was the fast expansion of the internal market and its strong aggregated demand, which held true for many countries in the region (De la Torre \& Pallares, 2017).

\subsubsection{Economic growth and governmental spending (2006-2014)}

The year 2006 brought major changes to Ecuador's economic path. With the election of Rafael Correa, a left-leaning president and member of the 'Pink Tide', the new government chose a state-led growth model focusing stronger on the internal market. In the following years, economic growth was mainly promoted by government consumption and investment, particularly in infrastructure. Most of the increase in public spending was financed through fiscal revenues from high commodity prices, especially for crude oil, but also non-oil commodities. Despite high tax revenues, the Correa government took on new external debt with Public debt/GDP amounting to 39.6\% in December 2016 compared to $15.1 \%$ in March 2010. Additionally, Ecuador's imports increased significantly due to higher wages, particularly in the public sector. Though exports continued to grow during that period, its growth could not keep up with the rise in imports resulting into a negative trade balance and low accumulation of reserves. In an attempt to alleviate this effect, taxes were imposed on imports and outflowing capital, which presented an additional source of fiscal funding (De la Torre \& Pallares, 2017).

In sum, the second period is characterised by three crucial developments. First, the Correa government strongly promoted inward-focused policies while economic potential was to be found outside the country's borders (high commodity prices combined with a weak dollar). Secondly, the steep rise in 
public spending was not matched with similar dynamics in the private sector. The sluggish development in the private sector can in parts be attributed to high fiscal expenditures causing an increase in prices and wages. Rising production costs rendered the private sector uncompetitive and private investment fell during this time period. Lastly, the government failed to build up reserves in its "Golden Years", and even worse, increased public debt during a time of strong economic growth and favourable external conditions. These factors increased the economy vulnerability towards the upcoming adverse macroeconomic developments and help to explain Ecuador's current economic crisis (De la Torre \& Pallares, 2017).

\subsubsection{The role of China in the "Golden Years"}

Though commercial and political ties between the countries developed throughout the early 2000s, China's importance for Ecuador gained momentum in the second sub-period of the "Golden Years". With rising public spending, Ecuador increasingly had to look for funding on the international markets (De la Torre \& Pallares, 2017). At the same time, diplomatic relations to the United States were seriously damaged through the unilateral shut-down of the military base in Manta, a town located at the Ecuadorian coast (Krauss \& Bradsher, 2015), and the expulsion of the American ambassador (Azpuru, 2016). In the same stroke, collaboration with multilateral institutions including the World Bank and the International Monetary Fund (IMF) was put on halt (Toussaint, 2007). To make matters worse, the Correa government defaulted on its governmental debt in 2008, which caused a shoot up in the country's risk premium and the exclusion from international financial markets (Krauss \& Bradsher, 2015). Eventually, this left China to fill the "lending vacuum". The new financier presented itself as a welcomed alternative to the government following its non- interventionist policy, which satisfied President Correa's demand for stronger political independence from the West. A similar re-orientation in terms of preferred donor countries took place throughout the whole region under the Pink Tide movement. Many of the left-leaning Latin American governments increased public spending while bilateral ties to traditional Western donors deteriorated (Skidmore, Smith \& Green, 2013). Thus, China was able to establish its political and economic presence not only in Ecuador, but throughout the Latin American region.

\subsection{The current economic crisis and contraction (2014-now)}

In 2011, the South American countries reached their growth peak, followed by a gradual economic slowdown due to decreasing commodity prices. Ecuador's economy kept relatively stable until the beginning of 2015 when oil prices suddenly plunged. At this point, it became apparent how Latin American countries managed their years of strong economic performance differently. Particularly Chile, Peru and Bolivia coped with the economic slowdown successfully which can largely be attributed to their prudent fiscal policy and the build-up of reserves in the years before the crisis. Furthermore, these countries were able to draw on an active monetary policy to buffer the shock. In contrast, Ecuador together with Argentina, Brazil and Venezuela faced severe recessionary trends. When looking at projected growth rates for the year 2017, many multilateral institutions predict an increase in GDP growth for most countries of the region, while Ecuador's economy is forecasted to further contract by $2.9 \%$ (De la Torre \& Pallares, 2017).

This growth trap is rooted in the aforementioned economic and fiscal conditions. The interplay of factors and their reinforcing nature construct a downward spiral and discourage political adjustment. Economic growth in the second period of the "Golden years" was largely based on state-led capital accumulation and consumption. With weakening economic performance, governmental revenue has plunged which forced fiscal adjustment. Lower public spending adversely affected aggregated demand,

\footnotetext{
$32 \mid$\begin{tabular}{l|l} 
Marble \\
Research \\
Papers
\end{tabular}
} 
which further deteriorated through lower wage levels and resulting lower private consumption. While many neighbouring countries adopted monetary policies in order to devaluate their currency, Ecuador's dollarized economy makes it impossible to regain external competitiveness through this channel. Instead, the only means of re-balancing Ecuador's disequilibrium in the real exchange rate (most common measure of country's external competitiveness). However, this implies much needed, but highly unpopular wage cuts in order to restore lower price levels (De la Torre \& Pallares, 2017).

In this context, the damage to Ecuador's private sector and the resulting vulnerability of the country's economy becomes ever more pronounced. Attempts to alleviate the adverse effects of Ecuador's economic crisis through governmental spending is likely to provoke inflationary pressures, hence harming Ecuador's already low competitiveness. Given the weak internal private consumption, a sustainable path out of the crisis is presented by promoting private sector development and a stronger focus on external demand. Another argument supporting the private sector focus is the high debt burden combined with Ecuador's rising risk premium, which make cuts in public spending inevitable (De la Torre \& Pallares, 2017).

However, dollarization presents an aggravating factor in this context. As mentioned above, the exchange rate does not move with market conditions, which is why Ecuador's money market is solely regulated through quantity (not price). In practice, this means that money supply expands with a balance of payment surplus while it contracts in times of deficit. Due to the appreciation of the dollar, imports are strengthened while exports are weakened. Additionally, increasing economic uncertainty promotes capital flight which further deteriorates the balance of payment deficit. Following the logic outlined above, the lower money supply eventually causes a credit crunch, which, in turn, hinders private sector development and economic recovery (De la Torre \& Pallares, 2017).

\subsubsection{The role of China in the current crisis}

The dynamics in Ecuador's money market increased its need for liquidity injection in recent years tremendously. Next to capital controls and import restrictions, measures that were adopted to alleviate but not contest the effects, borrowing in dollar terms presented the most effective policy (De la Torre \& Pallares, 2017). Due to its large foreign dollar reserves, China proved to be one of Ecuador's most important partners. Ecuador's increasingly desperate situation increased the lender's bargaining power enormously as Ecuador was practically forced to accept ever-worsening loan conditions (De la Torre \& Pallares, 2017). Due to reoccurring public debt defaults, the country historically shows a higher risk premium than its neighbouring countries (De la Torre \& Pallares, 2017). In this context, another "favourable" attribute of Chinese lending is its persistent financial support long after many Western financiers have already stopped funding (Economist, 2015). Another particularity about Chinese role in Ecuador's current economic crisis is represented by aggressive off-balance sheet activities, which the Ecuadorian government does not account for in official government debt. This mainly affects anticipated oil sales amounting to approximately $\$ 10.2$ billion between 2009 and 2016, with a large, but hardly detectable share of this contracts going to China (De la Torre \& Pallares, 2017).

Even though dollarization is a nearly unique feature among Latin American countries, the abovementioned dynamics were shown in large parts of the region, yet in less severe forms due to possible monetary interventions (De la Torre \& Pallares, 2017). Falling commodity prices hit the resourcedependent continent hard and resulted into a common need for liquidity. China adopted the function of "lender of last resort" in various Latin American countries such as Venezuela, which enabled the Chinese 
government to dictate the conditions of the contracts and forced many receiver countries to engage into (oil) presale activities (The Economist, 2015).

Lastly, the Latin America region is affected by the recent election of the American president, raising the importance of China. The consistent uncertainty inherent in Donald Trump's policymaking might adversely affect international trade harming particularly small Latin American economies dependent on foreign trade. Furthermore, trade with the United State might decrease due to the US government's promotion of the local economy, with the help of subsidies and trade barriers. Lastly, and particularly affecting Ecuador, expansionary fiscal policy boosting aggregated domestic demand raises inflationary pressure. In this case, the FED would be forced to raise interest rates which would adversely affect Ecuador through at least two channels. On the one hand, a further appreciation would render Ecuadorian businesses even less competitive. Additionally, higher US-interest rates aggravate Ecuador's debt burden substantially. These developments would increase Ecuador's already high dependence on Chinese funding in preventing a currency crisis (The Economist, 2016).

\section{China's foreign aid and public financing}

As an introduction to the motivational model underlying Chinese foreign finance allocation, the following paragraphs outline major characteristics, developments and drivers of Chinese fund provision. Nowadays, China is the largest donor of foreign assistance outside the OECD-DAC. Even though the level of Chinese foreign assistance is still relatively small compared to DAC scales, funds have grown at double-digit rates in the last 15 years (Zhang, 2016).

\subsection{The development of China's foreign assistance}

The provision of China's foreign assistance dates back to 1950, when the country supported the reconstruction and development in the Democratic People's Republic of Korea and Vietnam. In the following years, the scope of assistance was gradually broadened including not only socialist but also other developing countries independent from their adopted political regime. Major reforms towards an opening of the Chinese economy in 1978 caused a significant change in the form of aid provision towards a mutually-beneficial assistance in the context of South-South cooperation. The projects were to become more diversified in their sector base and flexible in their arrangements and structures. Further modification was supported by the change towards a socialist market economy in the 1990s, which increased and diversified sources of aid funding (Information Office of the State Council, People's Republic of China, 2011).

In the first decade of the 2000s, China's tremendous economic development supported growth in aid funds and its importance in the world community regarding development assistance. Particularly the financial crisis of late 2008 emphasised China's prominence as "new donor" country as traditional Western donors significantly cut their aid budgets due to economic recession and budget deviancies (Diaz, Jr. \& Lee, 2009). In 2013, China provided 3.9\% of total development assistance, a share that can be expected to grow taking into account the economic slow-down in Western economies due to structural and demographic problems which are projected to aggravate in the future (Zhang, 2016).

\footnotetext{
$34 \mid \begin{aligned} & \text { Marble } \\ & \text { Research } \\ & \text { Papers }\end{aligned}$
} 


\subsection{Characteristics of China's foreign assistance}

According to the White Paper on foreign aid (Information Office of the State Council, People's Republic of China, 2011), Chinese development assistance bases on five core principals. It emphasises the importance of self-development of the recipient country through growth in local resources (1). The report further underlines China's status as a developing country. Hence, the bilateral relations between receiver and donor county are characterised by a mutually beneficial and equal exchange of resources (2). The most hotly debated characteristic of Chinese assistance lies in the principal of the non-interference policy implying that funding is provided regardless of the adopted political regime and economic development model of the receiver country (3). Lastly, the White Paper points out the importance of adapting assistance to local needs (4) as well as emphasising the necessity of innovation and reform (5).

In financial terms, aid is provided in the form of grants (1), including emergency relief and financial support of small projects in the social sector, interest-free loans (2), available to countries in good economic condition for the construction of public facilities, and concessional loans (3). The last type includes medium- and large-scale infrastructure projects in order to raise the receiver country's economic productivity and social welfare. Most assistant funds are provided in the form of bilateral cooperation though China increasingly participates in multilateral organisations in order to coordinate its development funding (Information Office of the State Council, People's Republic of China, 2011). Regionally, China's foreign aid funds strongly emphasise Africa with a lion share of $45.7 \%$ and Asia receiving $32.8 \%$ of total funds. Latin America accounts for a share of $12.7 \%$, though its importance in China's portfolio, particularly in less concessional forms of funding, is expected to grow in upcoming years (Information Office of the State Council, People's Republic of China, 2011).

Regarding its sectorial distribution, a major share is invested in infrastructure and industrial development, exemplified in the African case where $61 \%$ and $16 \%$ account for the respective sectors (Information Office of the State Council, People's Republic of China, 2011). Reasons for this particular distribution are debatable with China justifying its support with its own successful experience in infrastructure construction boosting domestic productivity while other, mostly Western sources, presume more egoistic motives promoting, in the first place, Chinese economic development. Taking the principle of mutually beneficial relationships into account, this reasoning matches China's aid guidelines to a certain extend. The most prominent form of "mutually beneficial" aid provision in this debate are so-called "complete" or "turnkey" projects, in which China assumes the responsibility for the entire projects, both in terms of capital (e.g. material etc.) and labour (e.g. Chinese experts and workers) (Tseng \& Krog, 2017). This project type accounts for $40 \%$ of China's foreign aid provision and has the obvious advantage of promoting its domestic economy using its own resources (Information Office of the State Council, People's Republic of China, 2011). On the other hand, the local economy of the receiver country does not gain from this form of project execution, which can be critically questioned against the background of China's principal of self-development.

\subsection{Economic interest in allocation of foreign assistance}

The most common reason put forward in the context of Chinese foreign finance allocation is the safeguard of natural resources (Tseng $\&$ Krog, 2017). In its $11^{\text {th }}$ Five-Year Plan published in 2006, China explicitly states the principal aims of maintaining economic growth while conserving energy and natural resources (Information Office of the State Council, People's Republic of China, 2011). In 2009, the country was already receiving over $50 \%$ of its petroleum from abroad with increasing trends predicted (Diaz, Jr. \& Lee, 
2009). This puts China in a vulnerable position, particularly due to the dependency on the Middle East. In an attempt to diversify its energy base, China has intensified its relationship with oil-rich countries in Latin America and Africa, in the latter case most notably with Venezuela, Brazil and Ecuador (The Economist, 2016). Next to petroleum, other raw materials such as copper, silver or tin are of crucial importance for the production of Chinese companies, which is why countries like Chile and Peru shift into the spotlight of Chinese economic interest (The Economist, 2016). Lastly, China is facing the pressure of the world's largest population being home to 1.3 billion inhabitants (Diaz, Jr. \& Lee, 2009). In order to secure a stable food supply in the future, the country is increasingly looking outward for land and crop supplies. Particularly, land-intensive crops like soybeans are purchased abroad, which is why Latin American countries further rise on the Chinese agenda (Diaz, Jr. \& Lee, 2009). Besides the interest in natural resources, financial flows to Latin America are also aimed at establishing and growing new export markets for Chinese products. Particularly infrastructure investments are an important step to improve the distribution of Chinese imports in Latin America as well as to develop the general business environment for Chinese companies operating locally (Lengauer, 2011).

\subsection{The role of institutions in allocation of foreign assistance}

In order to understand China's view on foreign assistance in the context of institutional development, it is crucial to compare it with stances of Western donors, in particular the US. Throughout most of the $20^{\text {th }}$ century, the US exerted strong influence in the Latin American region (Skidmore, Smith \& Green, 2013). During the Cold War, US presence was ideology-driven opposing its communist counterpart in the East (Piccone, 2016). The country's intelligence service involved heavily in sabotaging left-wing governments with the most famous example being the coup against Chile's socialist president Salvador Allende in 1973 laying the basis for one of the darkest chapters in Chile's history (Skidmore, Smith \& Green, 2013). With the collapse of the Soviet Union in the early 1990s, Western motivations underlying foreign assistance changed towards the promotion of free-market economies within the framework of democratic and liberal states (Tseng \& Krog, 2017). In this context, political freedom, democratisation, good governance and the respect of human rights became preconditions for foreign finance provision (Tseng \& Krog, 2017). Besides purely ideological motivations driving these development goals, the US also pursues practical motives. (Illegal) immigration is one of the most hotly debated topics in American politics contributing to the success of Donald Trump in last year's elections. Promoting strong and stable institutions is an essential step in alleviating the pressure of legal and illegal immigrants. The same arguments holds for drug production and trafficking, both reason and consequence for institutional instability (Piccone, 2016). Thus, the stabilisation of Latin American institutions is critical for the American government in order to tackle issues of domestic security and social cohesion.

China takes a widely different stance on institutional development within its receiver countries. Its noninterference policy clearly addresses the importance of sovereignty and independence of receiver countries. The reasoning is based on the notion of South-South cooperation between developing countries, resulting in cooperation at eye-to-eye level (Information Office of the State Council, People's Republic of China, 2011). Thus, Chinese foreign finance is theoretically provided independently of the receiver countries' institutions and their chosen development model. Furthermore, large geographical and cultural distances between their continents makes drug trafficking and immigration of negligible concern for China. However, both the US and China share their interests in stable and robust economic growth within their export and import markets, hence in strong institutions in the Latin American countries which are a crucial pre-condition governing economic interaction (Piccone, 2016). High corruption, a weak rule of law and an 
inefficient bureaucracy, to name just a few, hinder market exchange and economic growth. Thus, it can be concluded that China shares the Western interest in institutional stability in the context of receiver country's stable business environment and market conditions. However, China does not interfere in "normative institutional politics" concerning more philosophical decision about state development.

\subsection{Political interest in allocation of foreign assistance}

With the rise of China as a new superpower challenging America in its traditional domains, the region has gained political importance. This power struggle has been further aggravated by the US' military presence in Asia, particularly in the South Sea, which dares China in its backyards (Piccone, 2016). In the 2000s, the US presence in Latin America diminished due to increased engagement in the Middle East. Furthermore, the financial and economic crisis presented a prime concern for policy makers in the end of the first decade (Diaz, Jr. \& Lee, 2009). Under these circumstances, China took its chance to fill the vacuum. With the election of Donald Trump, the space for political and economic manoeuvre has only widened due to the US government's focus on its domestic economy, which has gone hand in hand with hostility towards Latin America, particularly on the topic of immigration and trade. Furthermore, the failed agreement on the Trans-Pacific Partnership (TPP) presents an opportunity for China to expand its geopolitical power on the continent (Piccone, 2016). An alternative, such as the Regional Comprehensive Economic Partnership, excluding United States while including India and Japan would considerably promote China's political sphere of influence not only in Latin America, but also on the global stage (Piccone, 2016).

Such development supports another of China's political aims, namely the quest of increased international considerations in multilateral institutions, many of which being strongly influenced by the US (Lengauer, 2011). Lastly, the One-China policy still ranks high on the Chinese foreign policy agenda, which addresses the existence of two governments claiming the legitimacy over "One China" (Tseng \& Krog, 2017). Nowadays, twenty-two governments still maintain diplomatic relationship with Taipei, twelve of them being located in Latin America and the Caribbean (The Diplomat, 2016). In order to pursue its political aim, China uses preferential trade terms and financial assistance, with the latest example being the recognition of Beijing by Costa Rica in 2007 (Piccone, 2016)

\section{A general model of foreign finance allocation}

The preceding paragraphs covering the characteristics of Latin America's economic and political development (exemplified at the case study of Ecuador) as well as the path and motivation underlying Chinese foreign finance define the conditions and pay-offs within the bilateral relationships. Hence, this qualitative analysis is used in order to develop a more general model of China's underlying motivation in providing foreign assistance (see Figure 1), which can be empirically tested. The model builds in parts on the research of Dreher et al. (2015), who performed similar studies in the African context. The empirics in this paper take a different angle conducting the research based on a Latin America country sample. 


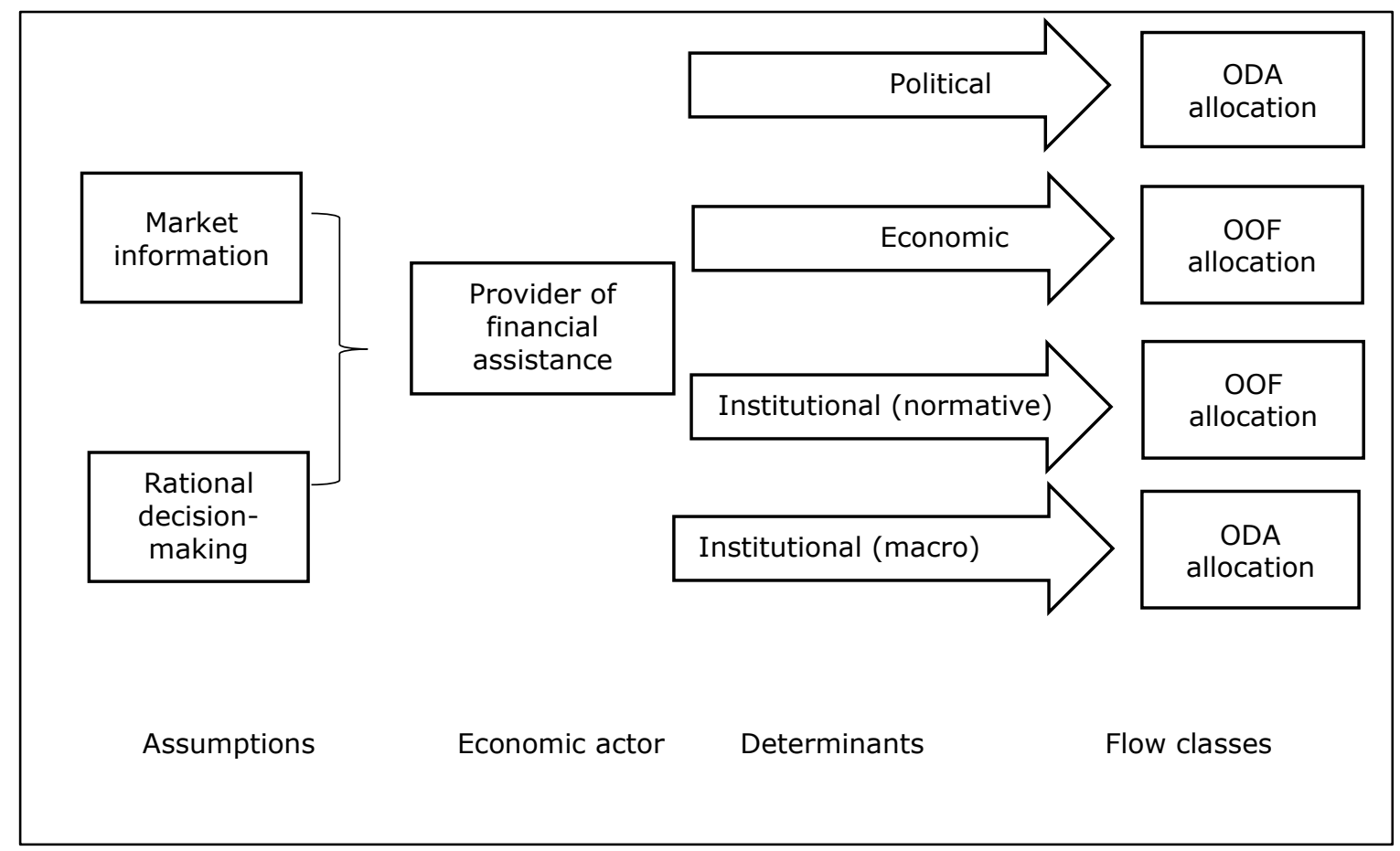

Figure 1: Motivational framework underlying Chinese public financing

The model distinguishes two types of flow classes (ODA/ OOF). It assumes different determinants underlying ODA and OOF flows, which are derived from the preceding analysis of Chinese interests in foreign finance allocation. Hence, they are grouped into the three categories of political, economic and institutional drivers (see Figure 1).

As aforementioned, ODA flows are concessional in nature and aimed at the economic and social advancement of the receiver country. However, next to purely altruistic motives, donor countries interests' are also determined by more egoistic motivations. Along these lines, ODA flows are found to support the political interest of the donor country (Dreher et.al., 2015). Alesina and Dollar (2000) find that foreign aid allocation is mainly driven by political and strategic consideration while economic needs and policy performance play only a minor role. Similarly, Schraeder, Hook and Taylor (1998) reject the idea that foreign aid is purely driven by altruistic motives while emphasising the importance of strategic and ideological considerations. The authors also find that trade relation plays a significant role in aid allocation. Following the preceding analysis of politically motivated foreign finance allocation, which outlined the strategic importance of Latin America for China as "America's backyard", its votes in multilateral institutions and the"One China policy" the following hypothesis develops in this context:

H1: Chinese ODA allocation in Latin American countries is driven by the alignment of political stances of receiver countries with Chinese political interests in order to promote China's political power on the international stage.

In contrast to ODA, OOF do not primarily focus on receiver countries' development, which is why they are less concessional in nature. Therefore, this flow class is more similar to investments based on indicators measuring the receiver countries' economic strength and stability as the underlying motive is the advancement of the donors' economic interests by allocating OOF considering the most beneficial riskreturn relationship between countries. Taking into account the analysis of Chinese economic interest in

$38 \mid$\begin{tabular}{l|l} 
Marble \\
Research
\end{tabular}

Papers 
fund allocation, which considered the promotion of trade relationships, export markets and resource security, the following hypothesis is tested:

H2: Chinese OOF in Latin America are allocated following determinants measuring strength and stability of the receiver country's economic environment in order to best serve China's economic demands.

Lastly, institutional considerations are both important to ODA and OOF allocation (see also 4.4). However, the nature of institutional determinants differs largely when examining the motives behind the different flow classes. Along these lines, institutional variables can be grouped into two categories, namely "normative institutional variables" and "investment environment institutional variables".

The grouping of the latter category follows the idea that high institutional quality creates an environment promoting innovations, entrepreneurship and technological progress, which translates into higher economic growth (Bruinshoofd, 2016). According to North (1991), institutions are defined as "humanly devised constraints that structure political, economic and social interaction" (p.97). In essence, North (1991) states that institutional quality improves with higher constraints on executive power, through both formal and informal channels. This idea is motivated by the notion that investments are protected from arbitrary expropriation. Thus, technological, capital and human investments, which include some degree of uncertainty by nature, are more likely to be carried out by participants of the economy as unpredictability of returns above the natural level decreases significantly. Acemoglu, Johnson and Robinson (2001) follow a similar line of thoughts when predicting institutional quality with the de facto protection of investments against expropriation. A further component characterising the group of "investment environment institutional variables" is the effective administration of public services including, among others, infrastructure and quality of bureaucracy. According to Easterly (2014), the provision of rights stays ineffective as long as they are not administrated through a well-functioning and transparent public service sector. Thus, an efficient and effective bureaucracy is crucial in order to exploit the economic potential of an economy. Lastly, the control of corruption is critical to the efficient allocation of resources within the economy, which shapes the potential to realise economic opportunities (Baumol, 1990).

In summary, the group of "investment environment institutional variables" attempts to measure the long-run economic potential of an economy and the degree to which conditions are enabling individuals to realise this potential. Therefore, these variables are crucial to investors of oOF as they determine the risk-return relationship of their investment. In the context of the conducted research, the following hypothesis is investigated:

H3: Chinese OOF allocation in Latin America follows determinants of strong and stable institutional environments which positively impact the risk-return relationship of Chinese investment in receiver countries.

In contrast to the aforementioned discussion, the research on "normative institutional variables" shifts the focus towards individual rights. However, the distinction remains blurry in many cases as concepts are highly interrelated. Variables in both categories can be used as predictors of long-run economic growth. The main difference represents the logical point of departure and the motivation to provoke change of donors. According to Easterly (2014), sustainable long-run economic growth can only be based on respect of personal rights. He argues that investments are only taken out if individuals have the opportunity to exercise the right to benefit from the investments within society. Elaborating on this thought, these rights 
do not only include economically important property rights, but widen the spectrum towards human, civil and political rights.

Next to its economic and social potential, characteristics in the "normative institutional variables" category are often found to be desirable in themselves due to ethical reasons and political convictions. At the same time, these determinants are considered to be necessary pre-conditions for a well-functioning society, especially following Western world views. The degree of democratisation serves as an example for this group of variables. The political system is considered to be crucial for public investors when entering a country as supporting an authoritarian regime disrespectful of human rights stands in stark contrast of the Western value systems.

In summary, the group of "normative institutional" variables emphasise an "ethical, sociopolitical" mandate to promote a change towards democratic and inclusive institutions, with economic returns being of secondary importance. Therefore, these variables can be expected to drive ODA allocation as an attempt by public investors to bring about a positive change in the receiver countries' civil society. Though this argumentation is likely to hold in the case of traditional Western donors, its applicability in Chinese foreign finance allocation is highly questionable. The Chinese government clearly states a noninterventionist approach when providing development assistance. It implies that the Chinese state does not follow an ethical, socio-political mandate in the allocation of ODA flows which would influence receiver countries' internal affairs. Thus, the last hypothesis reads as follows:

H4: Chinese ODA allocation is independent of de facto political regimes of receiver countries and the status quo of human and civil rights.

\section{Data and method}

\subsection{Dependent variables}

The (logged) monetary value of Chinese foreign finance projects to recipient countries (in constant 2009 USD) is used as the main dependent variable. Data are retrieved from the website "China. aiddata.org", which has the project aim of making Chinese development finance flows more transparent and accessible. Because China does not disclose official figures on its foreign financing, this database represents the best available choice aggregating public information on Chinese project work. Furthermore, China is not part of the OECD-DAC donors which is why the differentiation between flow classes is only an approximation of ODA-like and OOF-like projects. ODA-like projects include projects which focus on development support, such as grants, debt relief, loans with major grant element and technical advisory ("AidData- Open data for international development", 2017). OOF-like projects do not primarily focus on development objectives and include loans and credits with minor grant element ("AidData- Open data for international development", 2017). Within the sample, $54.7 \%$ of the ODA- and $44.1 \%$ of the OOF projects remain unverified as their monetary value is not disclosed or to be found in public sources, which is why these projects were excluded from the analysis.

\subsection{Explanatory variables}

In order to test for potential effects of alignment of receiver countries' political decisions with China regarding Chinese ODA flows (Hypothesis 1), receiver countries' voting behaviour within the United Nation General Assembly (UNGA) is analysed. Data are taken from "United Nations General Assembly Voting Dataset" by Voeten, Strezhnev and Bailey (2015). The database contains votes from 1946-2015 and ideal

\footnotetext{
40 Research Papers
} 
point estimates on voting alignment. A stronger alignment with China's political stances is expected to raise ODA flows. Furthermore, a binary variable on the One-China policy is included analysing whether the receiver country maintains diplomatic relationships with Taiwan. Within the sample, this variable shows little variation as only Costa Rica acknowledged Taiwan between 2001-2007 which needs to be taken into account interpreting the result.

To examine the potential effect of economic strength on OOF (Hypothesis 2), a set of four variables is included. (Logged) inflation, (logged) average interest on new external debt commitments and (logged) external debt stock as a percentage of GNI are incorporated as an approximation for the receiver country's ability to sustain its economic path, thus reflecting the donor country's investment risk. It is assumed that higher investment risk is likely to decrease OOF, though this effect might be offset by a high risk premium, rewarding risky investments with a potentially high return. In order to account for strength of existing trade relations, (logged) merchandise imports from low- and middle-income economies in East Asia \& Pacific as percentage of total merchandise import is included. Stronger existing trade relations are a sign of well-developed infrastructure between the countries which eases, and hence increases the return on OOF.

To analyse the relationship between OOF and strong institutions creating a positive investment environment (Hypothesis 3), a set of five variables is retrieved from the Political Risk Service (PRS) Group, Inc (2017). The variables are measured on a continuous interval scale and transformed using the natural logarithms. First, (logged) investment profile assesses the risk to investments with the subcomponents expropriation, profit repatriation and payment delays. A low score on investment profile is characterised by high investment risk, which negatively affects OOF. (Logged) law and order analyses another risk component focusing on legal protection of investments. Here, "law" refers to the degree of impartiality of legal system while "order" assesses the observance of law. High legal protection of investments is expected to influence OOF positively as investors' rights can be enforced, which reduces their investment risk. Similarly, (logged) government stability represents a measure of the government's capacity to take out decisions and stay in office. Though this variable might have negative consequences in both extremes, a relatively more stable political environment positively affects market sentiments and (OOF) investment. Related to government stability, (logged) bureaucracy quality analyses the strength and quality of public administration, hence the ability of new governments to change or revise former policies. In this sense, the variable represents another stability measure with effects expected to behave similarly to the ones outlined above. Furthermore, countries with high rankings of bureaucracy quality are generally characterised by higher political autonomy of their public administration, which negatively affects investment risk. Lastly, (logged) corruption measures the risk of bribery and other related activities within the political sector, which renders it inefficient, instable and unpredictable. High scores on corruption increase the investment risk, which reduces OOF to the receiver country.

Lastly, potential effects of de facto political regimes and the status of human rights on ODA flows (Hypothesis 4) are examined using a set of four variables from the aforementioned database. Due to China's non-interventionist policy, the following variables measuring normative directives are expected to be independent from Chinese ODA allocation. Particularly important within Western understanding of civil rights is governmental accountability and the existence of free and fair elections, which is measures by (logged) democratic accountability. For Western aid allocation, we would expect an inverse relationship between the variables as countries with low democratic accountability would be more likely to receive governance programmes financed by the international community (though this relationship again does not hold in its extremes). As mentioned above, no relation is expected between Chinese aid allocation and the 
accountability measure. Furthermore, both (logged) military in politics and (logged) religion in politics are included. Due to historical evidence, both government forms can be expected to reduce economic and political stability and limit human and civil rights such as freedom of speech or religious conviction. Moreover, there exist an inverse relationship with democratic accountability as both governments are not democratically elected, which is why the logic outlined above applies to both Chinese and Western aid. Lastly, (logged) socioeconomic conditions rates the risk of public discontent steaming from unemployment, consumer confidence and poverty. Though these societal problems still fall under internal politics, thus, China's non-intervention, the outcome for Chinese ODA allocation is ambiguous as particularly poverty measures show the need for development aid within the society. Hence, the relationship is expected to be positive if the latter logic applies or no relation exists if the common "non-interventionist" argumentation holds.

\subsection{Control variables}

Several variables are added in order control for potential influences on Chinese foreign finance allocation. GDP per capita is included in order to account for the general income level of the population. It is assumed that countries with lower levels of GDP per capita attract higher levels of ODA flows. On the contrary, OOF flows are expected to behave inversely as higher GDP per capita is a sign of economic strength. In a similar fashion, population (total) is added because a higher number of inhabitants indicates a higher need for aid flows (ODA). However, it could also be speculated that countries with smaller populations attract more ODA flows because the ratio of inhabitant to aid is lower which potentially increases the impact of the investment. (Logged) net bilateral aid flows from the European Union institutions and net bilateral aid flows from the United States are included with the underlying notion that countries compete on aid flows as a way to increase their political influence vis-à-vis with other donor countries. Lastly, oil rents as a percentage of GDP and total natural resource rents as a percentage of GDP are added accounting for the potential increasing effect of natural resources on foreign finance. In the case of both ODA and OOF, greater natural resource endowment is expected to attract investments in order to get access to resourcerich countries.

Most of the explanatory variables are transformed using the natural logarithm in order to insure comparable scales and a better interpretation of resulting coefficients. In case of negative data points, a small constant is added in order to conduct the logarithmic manipulation. Only in the case of net bilateral aid flows from the United States, the numbers are big and negative, which is why the previously mentioned method cannot be applied. Instead, all data points are divided by 10.000 .000 to scale the variable down. Dummy variables are not manipulated in any way.

\subsection{Statistical method}

The model is estimated using Ordinary Least Square (OLS) regressions. Though fixed effect regressions would have the advantage of reducing endogeneity problems in the form of omitted variable bias across countries, the relatively low variation in the explanatory variable within countries does not allow for the use of this specification. Instead, the econometric analysis focuses on across country variation to test the hypotheses in the form of OLS regressions. Furthermore, the data set is transformed into panel data and standard errors are clustered on the country level to account for dependent observations within the explanatory variables.

\section{$42 \mid$\begin{tabular}{l|l} 
Marble \\
Research \\
Papers
\end{tabular}}


In order to test the hypotheses, the following equation is estimated:

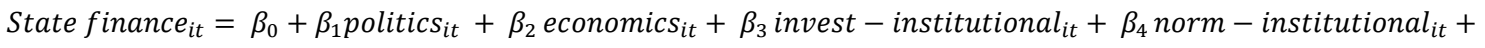

$$
\beta_{5} \text { control }_{i t}+\varepsilon_{i t}
$$

where state finance refers to either ODA or OOF to the receiver country $i$ in year $t$. Politics denotes the vector consisting of the two political variables outlined above. Economics includes the set of four variables testing Hypotheses 2. Invest-institutional and norm-institutional refer to the two different sets of institutional variables estimating Hypothesis 3 and 4 respectively. Lastly, control captures the six control variables mentioned above. $\varepsilon$ refers to the statistical error term.

\section{Results}

The hypotheses are tested using a sample of nine Latin American countries (Argentina, Bolivia, Brazil, Colombia, Costa Rica, Ecuador, Mexico, Peru, Venezuela). The analysis covers a time period from 20012011, excluding the proceeding economic downturn in the region.

With regards to Hypothesis 1 (Table 1), voting alignment with China in the UN leads to insignificant results with an unexpected negative coefficient. An analysis of Pearson correlations is added in order to further examine the nature of relationships between variables analysed in Hypothesis 1 (Table 2).

Table 1: Allocation of China's state financing: H1 (ODA, 2001-2011, OLS)

\begin{tabular}{ll}
\hline & ODA (log) \\
\hline UN voting alignment (log) & $-2.885(0.422)$ \\
One China Policy & $3.407 * *(0.012)$ \\
\hline GDP per capita (log) & $-0.322(0.887)$ \\
Population (log) & $1.562(0.142)$ \\
Aid by EU institutions (log) & $1.989(0.153)$ \\
Aid by US (transformed) & $-0.004(0.737)$ \\
Oil rents as \% of GDP (log) & $-0.741(0.508)$ \\
Natural resource rents as \% of GDP (log) & $-0.175(0.910)$
\end{tabular}

*.10,**.05;***.01 level

The simple correlation between ODA and UN ideal points (Table 2) shows an insignificant negative relationship. However, the recognition of China as the only sovereign state within the Taiwan conflict influences Chinese ODA allocation significantly positive (Table 1). Nevertheless, this finding needs careful interpretation as the low variation within the variable renders this result less credible.

The EU- and the US-aid variables are insignificant which might suggest that competition between donor countries does not play a major role (Table 1). Additionally, simple correlations between ODA and both aid variables show strongly significant negative relationships (Table 2), which is suggestive for a division of influence spheres between donor countries in order to avoid direct confrontation. 
Table 2: Pearson Correlation ODA and variables Hypothesis $1(n=33)^{2}$

\begin{tabular}{|c|c|c|c|c|c|c|c|}
\hline & $\begin{array}{l}\text { UN } \\
\text { POINTS }\end{array}$ & EU AID & US AID & $\begin{array}{l}\text { POPU- } \\
\text { LATION }\end{array}$ & $\begin{array}{l}\text { GDP } \\
(\mathrm{PC})\end{array}$ & $\begin{array}{l}\text { OIL } \\
\text { RENTS }\end{array}$ & $\begin{array}{l}\text { RE- } \\
\text { SOURCES }\end{array}$ \\
\hline ODA & -0.19 & $-0.56 * * *$ & $-0.67 * * *$ & $-0.47 * * *$ & 0.09 & -0.02 & -0.12 \\
\hline
\end{tabular}

*.10,**.05; ***.01 level

2 Years without ODA flows are excluded from the analysis

There is no support for the need-based aid allocation logic outlined above as GDP per capita and population provide insignificant results (Table 1), with correlation coefficients diverging from the abovementioned expectations (Table 2). Interestingly, both variables measuring natural resource endowment are insignificant with (unexpected) negative coefficients (Table 1). These results would suggest a contradiction to the widely held belief that Chinese aid is being used in order to access natural resourcerich countries, findings that are in line with Dreher et al. (2015).

In sum, the findings show only weak support for $\mathrm{H} 1$ as politically motivated allocation behaviour cannot be derived from the results outlined above.

The results for Hypothesis 2 show no significance within the risk-return variables, though average interest rate on new external debt commitment (negative), external debt stock as a percentage of GNI (negative) and merchandise imports from low- and middle-income economies in East Asia \& Pacific (positive) show the expected sign of the coefficient (Table 3). Insignificant results might possibly be due to data limitations, which would explain the low explanatory power. Another potential interpretation underlying these findings could lie in the nature of Chinese contract terms, with investors hedging investment risk through high collateralization. This would imply that China invests, to some extent, independently from the receiver country's risk profile as investments are well secured.

Table 3: Allocation of China's state financing: H2 (OOF, 2001-2011, OLS)

\begin{tabular}{ll}
\hline & \multicolumn{1}{c}{ OFF (log) } \\
\hline Inflation (log) & $0.089(0.967)$ \\
Average interest new ext. debt (log) & $-4.857(0.156)$ \\
External debt stocks (log) & $-1.499(0.492)$ \\
Merchandise imports East Asia \& Pacific & $1.639(0.674)$ \\
\hline GDP per capita (log) & $5.659 * * *(0.010)$ \\
Population (log) & $-1.324(0.191)$ \\
Oil rents as \% of GDP (log) & $-2.063(0.240)$ \\
Natural resource rents as \% of GDP (log) & $4.385 * *(0.032)$
\end{tabular}

$* .10, * * .05 ; * * * .01$ level

Most control variables provide expected results with GDP per capita being highly significant at the $1 \%$ level (Table 3 ). The result suggests that strong economies attract higher levels of oOF allocation, which is in line with the expectations. Quantitatively, this finding would be interpreted as a $1 \%$ increase in GDP per capita raising Chinese OOF allocation by $5.6 \%$. Additionally, the findings indicate a significant positive influence of natural resource endowment on OOF allocation (Table 3). This further supports the finding of Dreher et.al. (2015) and highlights the importance of discriminating between flow classes in development finance allocation, both in the African and the Latin American context. In sum, Hypothesis 2

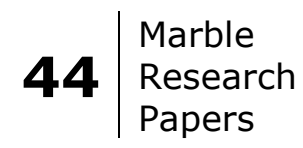


receives only weak support though highly significant GDP per capita and the sign of the coefficients of other variables point into the expected direction.

The results of Table 4 (Hypothesis 3) are largely in line with Table 3 with GDP per capita and natural resource endowment showing significant positive coefficients. Only investment profile is significant at the $5 \%$ level, though with a (diverging) negative coefficient. Four out of five institutional variables show unanticipated sign of coefficients, which support the above-mentioned theory of well-collateralised investments.

Table 4: Allocation of China's state financing: H3 (OOF, 2001-2011, OLS)

\begin{tabular}{|c|c|}
\hline & OOF (log) \\
\hline Investment Profile (log) & $-11.984 * *(0.028)$ \\
\hline Government Stability (log) & $-0.947(0.827)$ \\
\hline Law \& Order (log) & $-2.832(0.257)$ \\
\hline Bureaucracy Quality (log) & $3.265(0.448)$ \\
\hline Corruption (log) & $-4.290(0.288)$ \\
\hline GDP per capita (log) & $2.357 *(0.088)$ \\
\hline Population (log) & $0.930(0.409)$ \\
\hline Oil rents as \% of GDP (log) & $-6.664 * * *(0.001)$ \\
\hline Natural resource rents as \% of GDP (log) & $4.304 * *(0.036)$ \\
\hline \multicolumn{2}{|c|}{$\begin{array}{l}\text { In line with the aforementioned expectations (Hypothesis 4), the "normative insti } \\
\text { variables" lead to insignificant results while the signs of the coefficients do not reveal further infor } \\
\text { on aid allocation either (Table 5). Both the control variables included in order to test for the } \\
\text { argument of the population (GDP, population) as well as US and EU aid allocation result insigni } \\
\text { (Table 5). Interestingly, only oil rents as \% of GDP show significant, but negative effects (Table } 5\end{array}$} \\
\hline & ODA (log) \\
\hline Military in Politics (log) & $-4.832(0.287)$ \\
\hline Religion in Politics (log) & $5.304(0.797)$ \\
\hline Democratic Accountability (log) & $1.366(0.886)$ \\
\hline Socioeconomic Conditions (log) & $-1.108(0.785)$ \\
\hline GDP per capita (log) & $0.478(0.890)$ \\
\hline Population (log) & $-2.260(0.194)$ \\
\hline Aid by EU institutions (log) & $2.221(0.119)$ \\
\hline Aid by US (transformed) & $-0.012(0.646)$ \\
\hline Oil rents as \% of GDP (log) & $-3.863 * *(0.017)$ \\
\hline Natural resource rents as \% of GDP (log) & $-0.562(0.726)$ \\
\hline
\end{tabular}

*.10,**.05;***.01 level

Note. Data for Allocation for China's state financing from AidData- Open data for international development. (2017), and The PRS Group, Inc.. (2017), and DataBank- The World Bank. (2017). 
It could be reasoned that oil rich countries have more resources at their disposal in order to support their own population ("self-aid" instead of international aid). In sum, the findings support the claim of China's non-interventionist policy (Hypothesis 4) while they are not suggestive of strategic ODA allocation with regards to natural resources or political interests.

\section{Limitations}

Studies on Chinese state financing come with the inherent problem of lacking data availability, as the Chinese government does not publicly disclose the information. Thus, this study is based on data retrieved from a secondary source, which raises the question of accuracy and completeness. Furthermore, those projects from aid.data for which no monetary value was available were excluded from the sample, which significantly reduced the number of observations. However, aid.data presents the second-best solution and is regularly taken for academic research on Chinese development finance. In terms of sample size, only 9 out of 33 countries in the Latin American region are covered, which is a further result of data availability issues. Hence, the applicability of the results in a broader context is limited, though it might still be suggestive for Chinese public finance allocation in the region. Ideally, the sample period would have included more recent data in order to include the years of falling commodity prices which have caused an economic slowdown throughout the whole continent. The effect of the crisis developments on Chinese public allocation could provide further insides into underlying determinants, which should be exploited in future research. Moreover, the comparison between "traditional" Western donors and "new" donor countries like China was only partly covered within the research, but could not be thoroughly examined as this analysis lies beyond the scope of this work. Similarly, regional comparison (e.g. Africa) in terms of Chinese public finance might hold interesting insights for future research.

\section{Interpretation and implications}

In terms of ODA flows, variables driving Chinese allocation decisions cannot be identified. However, the findings suggest that Chinese aid in Latin American is far less strategically motivated compared to other regions. Neither competition between influence spheres nor natural resource endowments are found to be significant underlying motivator for aid provision by the Chinese government. Political decisions of receiver countries seem to be somewhat influential in allocation decisions, though this result seems not fully robust due to missing data variation. In sum, drivers of ODA allocation in Latin America remain to be identified in future research. Nevertheless, accusations of strategic motivations, which potentially cause inefficient or unfair allocation schemes, cannot be supported, either. Nevertheless, data limitation are likely to have influenced the results, which is why the findings should be interpreted in a suggestive, rather than deterministic or causal form.

The findings for OOF allocation differ largely from the aforementioned hypotheses. Particularly, economic-institutional variables are inversely related to OOF flows implying that weaker and more instable economies receive higher investments, which contradict intuitive understanding and open several possible interpretations. First, it cannot be ruled out that these findings result from the abovementioned data limitation. A second interpretation suggests that the Chinese government holds a fundamentally different view on institutional development, which is not in line with the theories of Douglass North, hence expectations outlined in Hypothesis 3.

Thirdly, a possible explanation could be offered by a third variable driving the underlying relationship. In academia, an ever-growing research field is devoted to the relation between natural 
resource endowment and slower development. It is found that resource-rich countries tend to show, among others, slower economic growth, less democratic accountability and more instable institutional systems (Sachs \& Warner, 1999; Ross, 2001). This dynamic, commonly referred to as 'resource curse', is driven by underlying effects such as the Dutch disease, lack of diversification in the economy, an increase in armed conflicts and weakened democratic movements though a detailed explanation of the underlying processes lies beyond the objectives of this paper. Based on these findings, the relationship between weak and unstable institutions, governments and economies, higher OOF and resource endowments in receiver countries could look as follows:

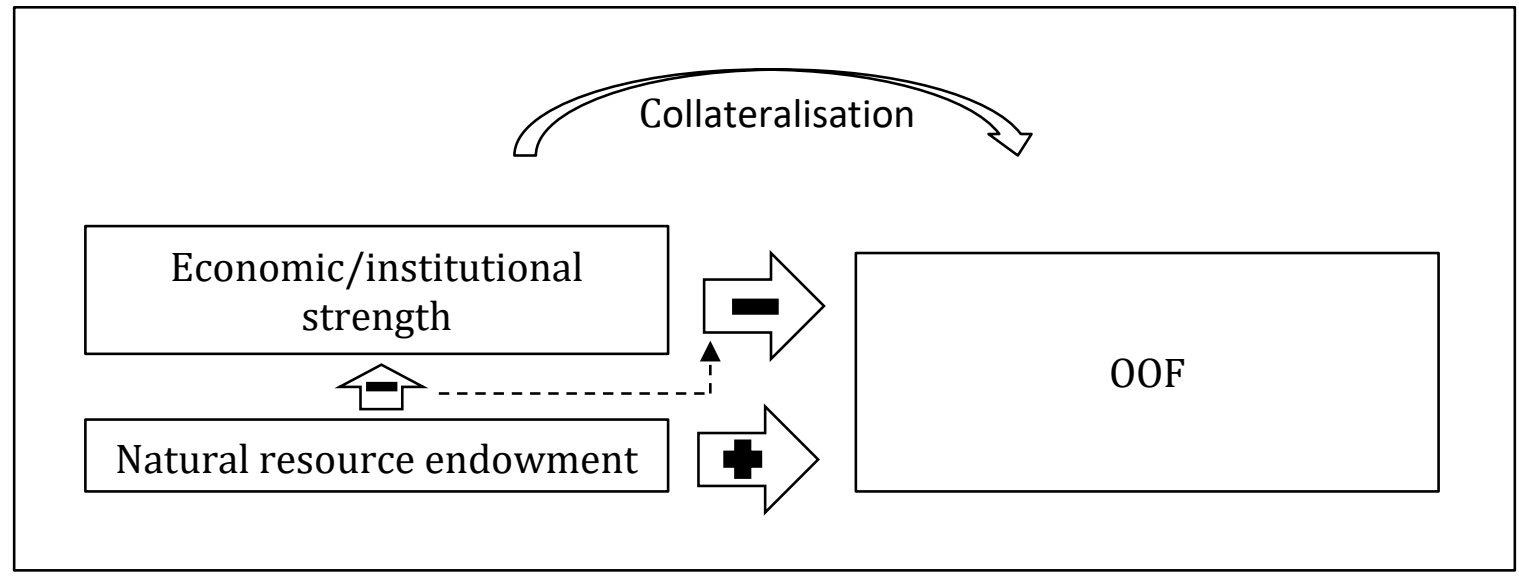

Figure 2: Effect of natural resource endowment on OOF

Natural resource endowment negatively influences economic and institutional stability following the resource curse hypothesis. In turn, weak and instable institutions deter investors, thus OOF, which is shown in the inverse relationship. Lastly, the high demand for natural resources from China is shown in the positive relation between those variables. Either the indirect negative effect of natural resources on the economy/institutions (in turn, OOF) or the direct positive effect of natural resources on OOF could dominate allocation decisions (see Figure 2).

In theory, the risk in the economy could rise to a level at which investors fear to lose out on their investments, which would cause them to pull their money out of the receiver country (indirect effect dominates). However, the statistical results suggest that the direct positive effect is predominant which could be explained by the contract structure of Chinese investments. In this context, collateralisation would serve as an instrument to hedge investment risk, which would leave the positive relationship of natural resources as the determining variable in OOF allocation. A forth explanation of the findings supports the "dominant resource hypothesis" as it could be theorized that China might use weak institutions within receiver countries to their advantage. Weak receiver countries' governments are characterised by corruption, political instability and lack of coherence, which would increase Chinese bargaining power. Hence, the Chinese state would be able to negotiate deals under their direction, possibly including collateralisation clauses.

These findings are highly relevant for resource-rich countries in the region as the dynamics outlined above weaken the incentives for politicians to take much needed reforms in order to reach a sustainable growth path. This can be exemplified at the Ecuadorian case, which currently struggles with a deep and potentially chronic economic crisis. Economic mismanagement can only be sustained until both the local population and foreign investors pull out their money. As the economy dries up, the government 
is forced to adopt structural reforms. However, well-collateralised investments prevent a capital flight by investors, hence, prolong economic mismanagement, which makes adapting reforms more difficult, painful and unlikely in the future. The longer this situation is upheld by Chinese liquidity injection, the more likely becomes a chronic economic or a major currency crisis, which would weigh much harder on the Ecuadorian populations than possible reform packages. In conclusion, the dynamics underlying oOF investment have both promising and destructive potential, which needs to be well understood by receiver countries' governments. After all, it depends on the government and its ability to resist the temptation of postponing unpopular reforms and benefit from the economic potential of OOF investments.

\section{Conclusion}

By examining the underlying determinants of Chinese public finance in the Latin American region, the paper provided at least two key contributions. Firstly, it analyses Chinese financing in a new regional context while most research in related fields focuses on the African continent. Secondly, a case study adds detail in analysing dynamics which underlie Chinese public investment on a country level. In terms of ODA flows, no support is found for either resource-driven, power-driven or institutionally-driven aid allocation while the findings seem somewhat suggestive for a political investment strategy. In terms of OOF allocation, the results indicate that natural resource endowments seem to be the major underlying driver. Besides, stronger economies attract higher levels of OOF flows while variables measuring institutional stability result inversely related and insignificant.

The findings point towards specific contract structures which allow China to hedge their investment risk. The significance of weak institutions in receiver countries lend support to this hypothesis as they enable the donor country to dictate the rules of the game. Additionally, Latin American governments have been eager to cover up liquidity outflows in the current account through foreign debt, which makes them willing to accept less beneficial borrowing conditions. The short-term liquidity injections enabled country leaders to hold on to power as the true dimension of the crisis remains concealed and unpopular structural reforms can be passed on to future governments.

In conclusion, China is an astute investor aiming to allocate funds in times of historically low returns. Its bilateral relations with Latin America seem skewed to benefit their economic and natural resource agenda, capitalizing on its momentum in Latin America's economic development. The success of this strategy is still to be validated with the ability to recover Chinese cash flows from receiver countries with ever-worsening credit conditions. For Latin American countries, Chinese foreign finance bears high potential in economic, political and social areas of development. However, it ultimately depends on receiver countries' institutional capacity and the ability of governments to capitalise on these benefits while resisting short-term gains in exchange for harmful and unpredictable long-run effects.

The results call for further research, both in the form of quantitative and qualitative analyses. Particularly, a study on Chinese contract structures within public and private projects might shed light on the hypothesised dynamics underlying OOF. Furthermore, a larger Latin American country sample as well as case studies on different countries in the region could be used in order to test the model of Chinese public finance allocation and the applicability Ecuador-specific dynamics in the larger context.

\footnotetext{
Marble

48 Research

Papers
} 


\section{References}

Acemoglu, D., Johnson, S., \& Robinson, J. (2001). The Colonial Origins of Comparative Development: An Empirical Investigation. American Economic Review, 91(5), 1369-1401. http://dx.doi.org/10.1257/aer.91.5.1369

AidData- Open data for international development. (2017). Aiddata.org. Retrieved 5 March 2017, from http://aiddata.org/

Alesina, A., \& Dollar, D. (2000). Who gives foreign aid to whom and why?.Journal Of Economic Growth, 5(1), 33-63. http://dx.doi.org/10.1023/A:1009874203400

Armony, A., \& Velásquez, N. (2015). Anti-Chinese Sentiment in Latin America: An Analysis of Online Discourse. Journal Of Chinese Political Science, 20(3), 319-346. http://dx.doi.org/10.1007/s11366-015-9365-z

Azpuru, D. (2016). Is U.S. Influence Dwindling in Latin America? Citizens' Perspectives. The Latin Americanist, 60(4), 447-472. http://dx.doi.org/10.1111/tla.12092

Baumol, W. (1990). Entrepreneurship: Productive, Unproductive, and Destructive. Journal Of Political Economy, 98(5, Part 1), 893-921. http://dx.doi.org/10.1086/261712

Bailey, M.A., Strezhnev, A. \& Voeten, E., (2015). Estimating dynamic state preferences from United Nations voting data. Journal of Conflict Resolution.

Broich, T. (2017). Do authoritarian regimes receive more Chinese development finance than democratic ones? Empirical evidence for Africa. UNU-MERIT Working Paper Series No. 2017-011. Maastricht, The Netherlands: Maastricht Graduate School of Governance/ UNU-MERIT.

Broich, T., \& Szirmai, A. (2014). China's Economic Embrace of Africa - An International Comparative Perspective. UNU-MERIT Working Paper Series No. 2014-049. Maastricht, The Netherlands: Maastricht Graduate School of Governance/UNU- MERIT.

Bruinshoofd, A. (2016). Institutional quality and economic performance. Utrecht: Rabobank. Retrieved from https://economics.rabobank.com/publications/2016/ january/ institutional-quality-andeconomic-performance/

DataBank- The World Bank. (2017). Databank.worldbank.org. Retrieved 8 March 2017, from http://databank.worldbank.org/data/

De la Torre, A., \& Pallares, J. (2017). La Trampa que Asfixia a la Economía Ecuatoriana. CordesCooperación De Estudios Para Desarollo, 1-42.

Diaz, Jr., M., \& Lee, R. (2009). China's Rising Interest in Latin America. China Business Review. Retrieved from https://www.chinabusinessreview.com/chinas-rising-interest-in-latin-america/

Domínguez, J. (2006). China's Relations With Latin America: Shared Gains, Asymmetric Hopes. InterAmerican Dialogue.

Dreher, A., \& Fuchs, A. (2015). Rogue aid? An empirical analysis of China's aid allocation. Canadian Journal of Economics, 48(3), 988-1023

Dreher, A., Fuchs, A., Parks, B., Strange, A., \& Tierney, M. (2015). Apples and Dragon Fruits: The Determinants of Aid and Other Forms of State Financing from China to Africa. SSRN Electronic Journal. http://dx.doi.org/10.2139/ssrn.2674601

Easterly, W. (2014). The tyranny of experts (1st ed.). Ney York: Basic Books.

Forbes. (2016). Undermining America while Washington sleeps: China in Latin America. Retrieved from https://www.forbes.com/sites/paulcoyer/2016/01/31/undermining-america-while-washingtonsleeps-china-in-latin-america/

Chinese public investment in Ecuador- an analysis of the motivational framework for Chinese state financing in the Latin American context 
González-Vicente, R. (2013). Development Dynamics of Chinese Resource-Based Investment in Peru and Ecuador. Latin American Politics And Society, 55(1), 46-72. http://dx.doi.org/10.1111/j.15482456.2013.00183.x

Harris, B., Gramer, R., \& Tamkin, E. (2017). The end of foreign policy as we know it. Foreign Policy Magazine. Retrieved from https://foreignpolicy.com/2017/04/24/u-s-agency-for-internationaldevelopment-foreign-aid-state-department-trump-slash-foreign-funding/

Huan-Kai Tseng, H., \& Krog, R. (2017). No Strings Attached: Chinese Foreign Aid and Regime Stability in Resource-Rich Recipient Countries.

Information Office of the State Council, People's Republic of China. (2011). China's Foreign Aid (pp. 1-6; 11-19). Beijing. Retrieved from https://www.unicef.org/eapro/China_White_Paper_on_Foreign_Aid.full_text.pdf

Jácome, L. (2004). The Late 1990's Financial Crisis in Ecuador: Institutional Weaknesses, Fiscal Rigidities, and Financial Dollarization At Work. IMF Working Papers, 04(12), http://dx.doi.org/10.5089/9781451842937.001

Kotschwar, B. (2014). China's Economic Influence in Latin America. Asian Economic Policy Review, 9(2), 202-222. http://dx.doi.org/10.1111/aepr.12062

Krauss, C., \& Bradsher, K. (2015). China's Global Ambitions, Cash and Strings Attached. The New York Times. Retrieved from https://www.nytimes.com/2015/07/26/business/international/chinasglobal-ambitions-with-loans-and-strings-attached.html

Lengauer, S. (2011). China's Foreign Aid Policy: Motive and Method. Centre For East West Cultural And Economic Studies, 9(2), 1-36.

North, D. (1991). Institutions. The Journal Of Economic Perspectives, 5(1), 97-112. Retrieved from http://www.jstor.org/stable/1942704

Piccone, T. (2016). The geopolitics of China's rise in Latin America (pp. 1-24). Washington, Brookings. Retrieved from https://www.brookings.edu/wp-content/uploads/2016/11/thegeopolitics-of-chinas-rise-in-latin-america_ted-piccone.pdf

Robles, F., Wiese, N., \& Torres-Baumgarten, G. (2015). Business in Emerging Latin America (1st ed.). New York: Routledge

Ross, M. (2001). Does Oil Hinder Democracy?. World Politics, 53(03), 325-361. http://dx.doi.org/10.1353/wp.2001.0011

Sachs, J., \& Warner, A. (1999). The big push, natural resource booms and growth. Journal Of Development Economics, 59(1), 43-76. http://dx.doi.org/10.1016/s0304-3878(99)00005-x

Schraeder, P., Hook, S., \& Taylor, B. (1998). Clarifying the Foreign Aid Puzzle: A Comparison of American, Japanese, French, and Swedish Aid Flows. World Politics, 50(02), 294-323. http://dx.doi.org/10.1017/s0043887100008121

The Diplomat. (2016). Is Latin America of strategic importance to China?. Retrieved from http://thediplomat.com/2016/12/is-latin-america-of-strategic-importance-to-china/

The Economist. (2015a). China's financial diplomacy: rich but rash. Retrieved from http://www.economist.com/news/finance-and-economics/21641259-challenge-world-bankand-imf-china-will-have-imitate-them-rich

The Economist. (2016). The economic consequences of Donald Trump. Retrieved from http://www.economist.com/blogs/freeexchange/2016/11/global-economy 
The Economist. (2016). A golden opportunity: China's president ventures into Donald Trump's backyard. Retrieved from http://www.economist.com/news/americas/21710307-chinas-presidentventures-donald-trumps-backyard-golden-opportunity

The Economist. (2017). China first: cutting aid and diplomacy will make America weaker. Retrieved from http://www.economist.com/news/leaders/21719481-donald-trumps-foreign-policy-will-deliveropposite-what-it-promises-cutting-aid-and-

The PRS Group, Inc.. (2017). The global leader in quant-driven political risk and country risk forecasts. Retrieved 9 June 2017, from https://www.prsgroup.com/

Skidmore, T., Smith, P., \& Green, J. (2013). Modern Latin America (8th ed.). Oxford: Oxford University Press.

United Nations. (2015). World Investment Report: Reforming International Investment Governance (pp. 30-64). New York/ Geneva: United Nations. Retrieved from http://unctad.org/en/PublicationsLibrary/wir2015_en.pdf

Van der Molen, M. (2013). The Tequila crisis in 1994. Utrecht: Rabobank. Retrieved from https://economics.rabobank.com/publications/2013/september/the-tequila-crisis-in-1994/

Wise, C., \& Quiliconi, C. (2007). Chinas Surge in Latin American Markets: Policy Challenges and Responses. Politics \& Policy, 35(3), 410-438. doi:10.1111/j.1747- 1346.2007.00067.x

Woods, N. (2008). Whose aid? Whose influence? China, emerging donors and the silent revolution in development assistance. International Affairs, 84(6), 1205-1221. http://dx.doi.org/10.1111/j.1468-2346.2008.00765.x

Zhang, J. (2016). Chinese foreign assistance, explained. Brookings. Retrieved from https://www.brookings.edu/blog/order-from-chaos/2016/07/19/chinese-foreign-assistanceexplained/ 